MOVERS

\section{Alex Dehgan, senior scientist and policy adviser, US Department of State, Washington DC}

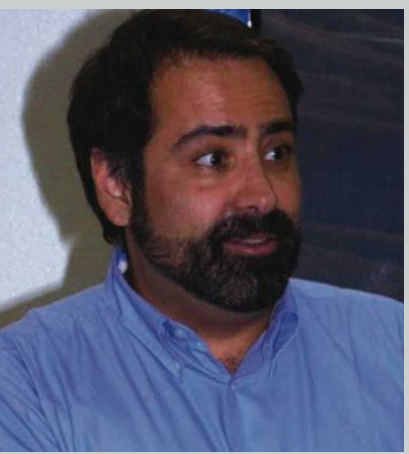

2006-07: Afghanistan country director, Wildlife Conservation Society, Kabul 2006: Member, policyplanning staff, Office of the US Secretary of State, Department of State, Washington DC 2005-06: Senior science fellow, World Conservation Union, USA Multilateral Office, Washington DC

As a young man, Alex Dehgan's diverse interests spanned conservation biology, environmental science, law and international trade. He ultimately pursued each, and, inadvertently, prepared for a career in foreign policy. His circuitous route has taken him from Madagascar to Iraq as he engaged people across disciplines as well as borders.

Dehgan graduated from Duke University in Durham, North Carolina, with a double major in zoology and political science. "Either way, I figured I was dealing with animal behaviour," he says. A trip to Madagascar for an undergraduate course in primate conservation influenced his future career path.

After earning a law degree to "better understand the social fabric that holds society together", Dehgan decided to return to conservation. He began his $\mathrm{PhD}$ at the University of Chicago, and later returned to Madagascar to study lemur populations in fragmented forestlands for his dissertation.

Despite his love of fieldwork, Dehgan decided to enter the policy realm to help conserve tropical forests. An American Association for the Advancement of Science policy fellowship placed him at the US Department of State. Although Dehgan had difficulty finding a niche, Norman Neureiter, the first scientific adviser to the state department, was so impressed with his background that he persuaded Dehgan to continue. "Alex's diverse interests and expertise were exactly what US foreign policy needs," says Neureiter, now the director of the Center for Science, Technology and Security Policy in Washington DC.

Dehgan was ultimately sent to Iraq to retrain weapons scientists in fields such as ecology and conservation biology. He also led efforts to establish the Iraq International Center for Science and Industry and reconstruct Iraq's Natural History Museum. And he supplied Iraqi scientists with electronic access to hundreds of scientific journals. "Science is one area that cuts across culture to engage people - why not integrate it into diplomacy and development?" he says. He later went to Afghanistan to conduct the first wildlife surveys in 30 years, collaborating with a team of native, yet novice, naturalists.

In his latest role as a senior policy adviser to the US Secretary of State's newest science adviser, Nina Federoff, Dehgan hopes to use science to buoy developing countries' economies and emphasize the relevance of climate change in foreign policy and nation-building strategies.

Virginia Gewin
NETWORKS \& SUPPORT

\section{Lab links with southern states}

The US Department of Energy's Oak

Ridge National Laboratory (ORNL) in Tennessee last week signed a 'mentorprotégé agreement' with Jackson State University (JSU) in Mississippi. As part of the three-year commitment, ORNL will serve as mentor to the entire school, and collaborations will be forged across research sectors common to the pair. ORNL will be able to award non-competitive subcontracts, or form collaborations to submit funding proposals to other agencies.

ORNL, which made a similar agreement with Morehouse College in Georgia last year, is the first national science laboratory to forge collaborative agreements with historically black institutes.

"If we can help our subcontractors find synergies with our researchers, better understand our contracting mechanisms and learn to draft solid proposals, they'll be better partners," says Will Minter, director of ORNL's small-business programmes.

Although the JSU agreement is new, the two institutions already have collaborations in computational chemistry, homeland security, biological sciences and nanomaterials. JSU computational chemist Jerzy Leszczynski has worked with ORNL researchers on carbon nanostructures. His project is one of several that should grow with larger funds from ORNL in the future. "We're not expecting Oak Ridge to give us a $\$ 10$-million cheque. We want the opportunity to grow our strong programmes," says Rita Presley, JSU's associate vice-president for research and sponsored programmes. Presley hopes a strong relationship with ORNL will help JSU secure more mainstream funding, not necessarily money set aside for historically black institutes.

Morehouse College administrators say that access to ORNL equipment, such as its supercomputing capabilities, will soon help them to do research with a national scope. Noting that ORNL's biofuels research is looking at cellulose conversion, James Brown, director of Morehouse's Office of Research Careers, contacted Duane Jackson, who studies termites efficient cellulose converters. Jackson is now working with a Morehouse chemist and botanist to identify useful termite gut enzymes, which will feed into ORNL's biofuels work.

ORNL continues to seek partners eager to forge research partnerships. Minter says that other national labs seem interested in tracking the progress of ORNL's collaborations. "This programme is an experiment, but that's what labs do," he says. Virginia Gewin

\section{POSTDOC JOURNAL}

\section{Serial postdoc}

It's a bad habit to get into. Postdoc positions are liberally scattered over the past 10 years of my CV, and it's got to stop. Well, something has to change, because my funding runs out in 12 months. So here's the deal: I find a permanent position by the end of the year or I move out of academia... Gulp.

It's hard to believe that it's been 10 years since I finished my PhD in cosmology. It's been 10 years since I made a galactic research leap and followed my growing interest in biology. And I've conducted 10 years of research in mathematical ecology and evolutionary biology, which has taken me to four countries and facilitated collaborations with a diverse array of biologists. At the start it was hell. But the collaborations gave me a research foothold. Now, looking back on seabirds, cows, sheep, frogs, DNA and equations, the range of problems and experiences has been a joy. Theoretical ecology brings a lot of job diversity.

So here I am, a well-travelled senior postdoc at the University of Lausanne. Lectureship applications have started, job searching is well under way, as is considering where my partner and I could live. Have I been a postdoc too long? Have I collaborated too much? And what if this career doesn't work? In the year to come l'll have to explore the possibilities and contact friends who have made the move out of academia. Kick the postdoc habit.

Jon Yearsley is a senior postdoc in evolutionary genetics at the University of Lausanne in Switzerland. 